\title{
Modular Water Squares (MWS) in Poznan - People- Friendly Solutions for Rainwater Management
}

\section{Anna Januchta-Szostak}

Poznan University of Technology, Faculty of Architecture, ul. Nieszawska 13C, 61-021 Poznań, Poland

Corresponding author: anna.januchta-szostak@put.poznan.pl

$\Gamma$ crossef http://dx.doi.org/10.5755/j01.sace.12.3.12659

Water Sensitive Urban Design (WSUD 2005) methods aim to retain, clean and use water in the place of the rain occurrence. The main research objective was to find people-friendly solutions for rainwater management in the catchment areas in Rataje district in Poznan. The pilot research and project applications covered the area of multi-family modern housing estates which require regeneration of built environment and greenery structures as well as individualization of the public space. A detailed analysis and inventory of impervious and green surfaces in Rataje district made it possible to select the locations for water squares as well as to calculate the capacity of the run-off from the particular catchment areas. In the determined places, model arrangements of MWS-s were prepared, taking into account not only the improvement in small retention capability but also the attractiveness of the MWS-s for the inhabitants. The "research by design" method was used to prepare the alternative arrangements of MWS-s, which were subsequently evaluated with the use of the IDEKWA method in order to compare the key features of good public spaces. The result of the research allowed to present model solutions and select the crucial features of MWS-s meeting the needs of the local residents as well as rainwater management requirements. Modular Water Squares, adjusted to the expected run-off capacity from the particular catchment areas, can efficiently prevent urban flooding. However, the sample solutions must be multiplied in order to achieve the desirable effect of rainwater retention on the scale of the whole city. Simultaneously, MWS-s function as playgrounds and meeting places for inhabitants. Another essential role of the squares is the "edutainment", which allows to raise the ecological awareness of the future generations.

KEYWORDS: public space, Poznan, rainwater management, modular water squares, water sensitive urban design.

The current trends in urban planning expressed in the New Charter of Athens (2003) and the Leipzig Charter (2007) highlight the need to shape compact and user-friendly cities, however, at the same time, they emphasise the wise use of natural resources. These two goals are sometimes difficult to reconcile as the density of urban development and the expansion of impervious surface area alter the natural water cycle, cause pollution and pose the threat of urban floods (UNESCO 2012). It is necessary then to improve the correlation between spatial and urban planning and water management mainly because water and greenery determine life quality in cities to a significant extent (Bergier et al. 2014). In Poland the "watershed approach" functions in planning documents and tools concerning water management but it is not adopted in urban planning. Particularly in cities, water management is based on collective water pipe -sewage systems which does not meet the

\section{Introduction}

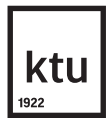

Journal of Sustainable Architecture and Civil Engineering vol. 3 / No. 12 / 2015 pp. $5-15$

DOI 10.5755/j01.sace.12.3.12659 (C) Kaunas University of Technology 
needs of small retention, while spatial planning of new building areas usually does not take into account the eco-hydrological consequences of urbanization (int.al. the expansion of impervious surface areas, overloading of collective sewage systems, changes in town watercourses' dynamics as well as threat of urban floods).

Water Sensitive Urban Design (WSUD 2005) aims to plan cities taking into account sustainable water management. "Watershed approach" in town planning is especially important regarding the predicted climate changes, particularly the increase in frequency of extreme hydro-meteorological phenomena occurrence, including both droughts and torrential rains. Solutions used in many countries such as Sustainable Urban Drainage Systems (SUDS), allowing to retain, clean and use water in the place of the rain occurrence, seem to be costly and space consuming. However, the possibilities of their multi-functional use and appealing form, can transform the elements of necessary infrastructure into socially desirable public spaces and, consequently, contribute to popularisation of eco-friendly solutions to the benefit of the environment, the community and the economy (Januchta-Szostak 2011). ARD theory (Artful Rainwater Design - Echols, Pennypacker 2006) claims that the social and landscape attractiveness of the blue-green infrastructure qualifies as the value added of the urban public space.

The main task of the research undertaken by the author was creation of Modular Water Squares (MWS) tailored to the specifics of local built environment in Rataje district and residents' requirements as well as the estimated rainfall volumes in Poznan. The MWSs were subsequently evaluated with respect to the key attributes of good, multifunctional public space.

\section{Methods}

\section{"Watershed approach" to urban planning - research methodology}

The aim of the multi-stage research performed at the Faculty of Architecture at Poznan University of Technology was to find such forms of housing estate areas' development which would not only justify rainwater retention for economic and environmental reasons but would also indicate the ways of using SUDS/TRIO systems to enhance the quality of public and neighbouring spaces.

In the first research stage ${ }^{1}$, the valid urban planning tools in Poland were analysed in terms of their usefulness for sustainable water management in cities as well as the examples of holistic approach to shaping public spaces were appraised (e.g. Boer et al. 2010). Different types of housing development (downtown quarters, detached houses, modernist multi-family blocks of flats and contemporary - developer housing) were also examined in selected Poznan areas in terms of the terrain insulation, the size of biologically active surfaces as well as public availability of recreation areas. The research proved that the modernist multi-family housing estates in Poznan have a great, unexploited potential for creating greenery and recreational infrastructure as well as rainwater management, because of high percentage of biologically active area ( $\geq 75 \%$ ).

In the second research stage (2014), a pilot area was selected, namely Rataje district in Poznan. It is a typical example of modernistic housing estate developed in a multi-stage hierarchical arrangement like many others emerging in Poland and other Soviet Bloc countries in the second half of 20th cent. Similarly to any average block of flats' area, Rataje district faces functional-spatial problems such as unification and spatial disintegration, architectural anonymity, low quality buildup and area development as well as car congestion. Previously planned district park along with recreational-sports infrastructure has not been realised and its prospective place has been filled with "wild" car parks and substandard garages. The district has a substantial open terrain which is currently under considerable developers' pressure due to the plans of increasing the development density (Fig. 1 - Rataje district before regeneration). The analyses of the district were performed within the scope of inter alia hypsometry, landform, functional-spatial structure (including recrea-

\footnotetext{
1 Including the results of the research project 10/01/DSPB/0242 Poprawa jakości przestrzeni squsiedzkich i publicznych w Poznaniu z wykorzystaniem systemów zrównoważonego zagospodarowania wód opadowych. (The Enhancement of Neighbouring and Public Spaces Quality in Poznan with the Use of TRIO Systems), financed by MNiSW in 2014.
} 
tional development), arrangement and quality of the landscape, eco-physiography etc. The detailed stocktaking of the ground covering and sealing of the housing estate terrain as well as the analysis of the directions of surface runoff made it possible to calculate the volume of the surface runoff from the individual catchment area as well as to select the places of small retention of rainwater. An opinion poll of the residents' needs was also conducted within the scope of public space development as well as the analysis of integration functions' arrangement in the housing estates.

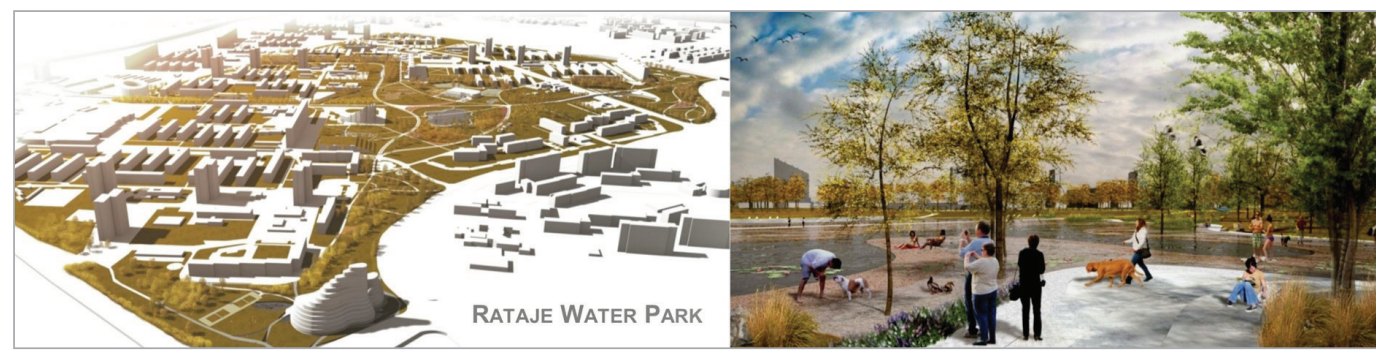

Modular character and the development standardisation foster system development within the scope of rainwater retention. On the other hand, however, the interiors between the blocks require individualisation and such spatial arrangements which enable different groups of residents to relax and integrate; while the individual housing estates need distinct landscape dominants defining the identity of the place along with spatial variety. The area requires urban and greenery regeneration as well as the
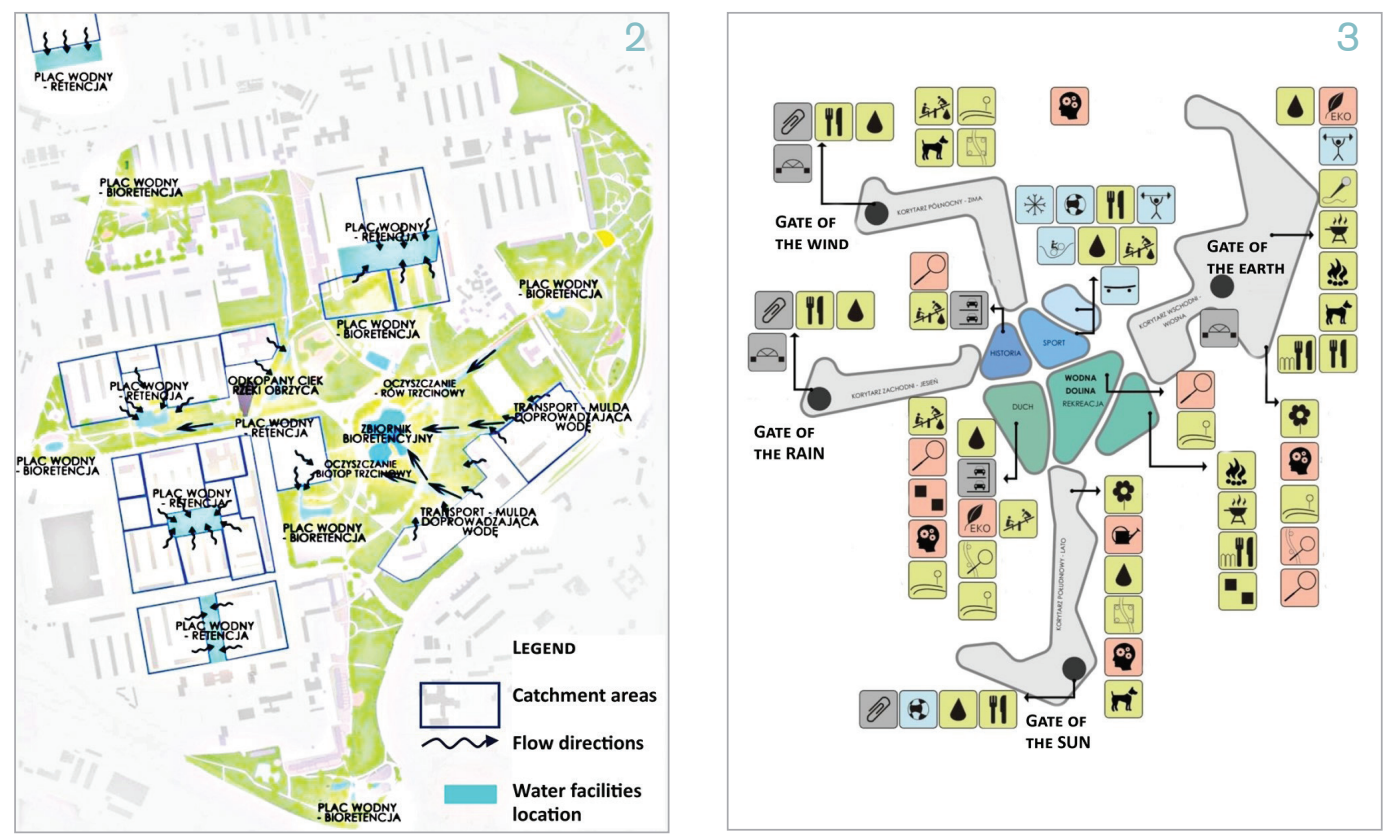

residents' life quality enhancement, especially in the face of visible society ageing processes. All the above mentioned issues indicate the choice of Rataje district as the pilot and project application area.

The research allowed to correlate hydraulic and functional-spatial factors which are indispensable for optimum location of water squares. As a result, an idea of Rataje Water Park² (Fig. 1) was developed along with the guidelines for the local spatial development plan. In the selected plac-

2 Rataje Water Park Project (2014) called Four Seasons' Park developed in 2013/2014 within MA project titled Rataje - Water Park in Poznan under the academic supervision of dr hab. inż. arch. A. Januchta-Szostak at the Faculty of Architecture at Poznan University of Technology. Authors: J. Grzelak, M. Małecka, K. Niewinowska, J. Nowowieska, S. Sobocińska, J. Stefańska. The project received commendation from Wielkopolska Voivode in the $24^{\text {th }}$ edition of competition called "Moja Wielkopolska".

\section{Fig. 1}

Rataje Water Park in Poznan - the concept of urban regeneration and spatial development. Authors: J. Grzelak, M. Małecka, K. Niewinowska, J. Nowowieska, S. Sobocińska, J. Stefańska under the academic supervision of dr hab. inż arch. A. Januchta-Szostak (Rataje Water Park 2014)

\section{Fig. 2}

The selection of the catchment areas and the location places suitable for water squares (Rataje Water Park 2014)

\section{Fig. 3}

The ideogram of Rataje Water Park functional development (Rataje Water Park 2014) 
es within the pilot area, the location of water facilities was suggested including water squares, rain gardens and retention ponds as well as reconstruction of former watercourse of the Obrzyca Stream (Fig. 2). The ideogram of Rataje Water Park (Fig. 3) shows the variety of functional development. The concept of the park and water facilities has been consulted with the representatives of Rataje district's inhabitants and local NGOs.

The following breakdown (Table 1) presents eight water squares which were selected for the further assessment. The comparison of the squares' capacity showed that the projects No 2, 3, 4 and 7 are tailored to average monthly rainfall in Poznan and the assumed capacity of the catchment areas, while the capacity of the squares No 1, 8 is oversized and much bigger than the estimated rainfall volume.

Table 1

The breakdown of variant water squares arrangements, sizes and capacities

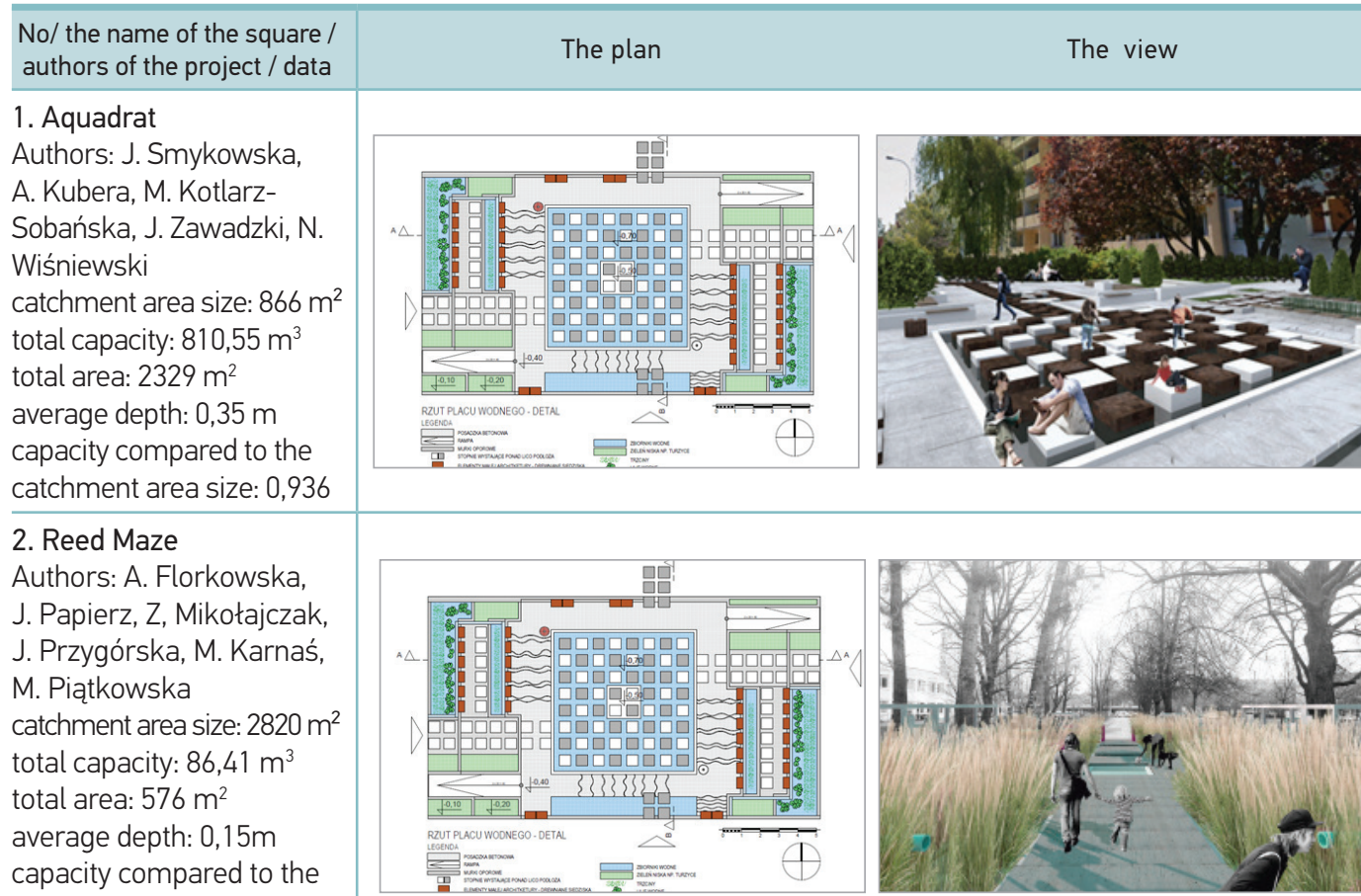

catchment area size: 0,031

\section{Hexwater}

Authors:

M. Sikorska,

A. Skurzynski

catchment area size: $572 \mathrm{~m}^{2}$ total capacity: $27,08 \mathrm{~m}^{3}$ total area: $215,08 \mathrm{~m}^{2}$ average depth: $0,126 \mathrm{~m}$ capacity compared to the catchment area size: 0,047

\section{Cruciform Water} Square

Author: M. Małecka catchment area size: $2838,4 \mathrm{~m}^{2}$ total capacity: $88,57 \mathrm{~m}^{3}$ total area: 958,04 $\mathrm{m}^{2}$ average depth: 0,09 m capacity compared to the catchment area size: 0,031
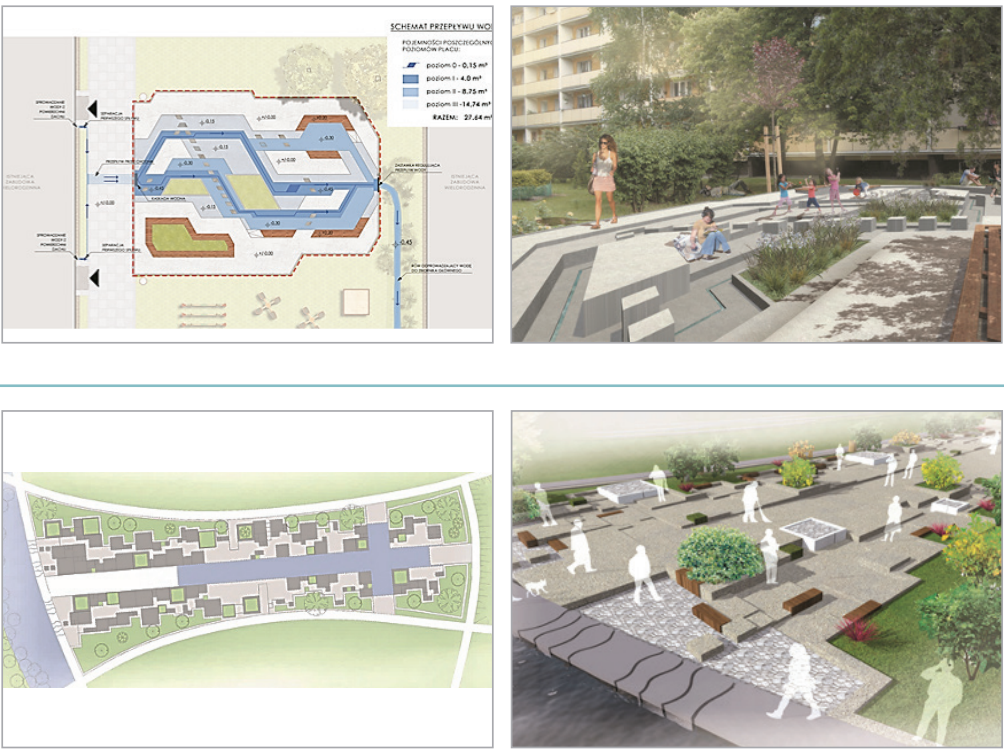


\section{Croissant}

Author: S. Sobocińska catchment area size:

$1244 \mathrm{~m}^{2}$

total capacity: $282,28 \mathrm{~m}^{3}$

total area: $865 \mathrm{~m}^{2}$

average depth: $0,33 \mathrm{~m}$

capacity compared to the

catchment area size: 0,227

\section{Rainy Gate}

Author: J. Grzelak

catchment area size: 6

$863 \mathrm{~m}^{2}$

total capacity: $858,42 \mathrm{~m}^{3}$

total area: $684 \mathrm{~m}^{2}$

average depth: 0,027 m

capacity compared to the

catchment area size: 0,125

\section{Rain Garden}

Author: K. Niewinowska catchment area size: 1733 $\mathrm{m}^{2}$

total capacity: $64,77 \mathrm{~m} 3$

total area: $41,5 \mathrm{~m} 2$

average depth: 0,03 m

capacity compared to the

catchment area size: 0,037

8. Water Pitch

Author: J. Nowowieska

catchment area size:

$2305 \mathrm{~m}^{2}$

total capacity: $2009,55 \mathrm{~m}^{3}$

total area: $2221 \mathrm{~m}^{2}$

average depth: 0,9 m

capacity compared to the

catchment area size: 0,872
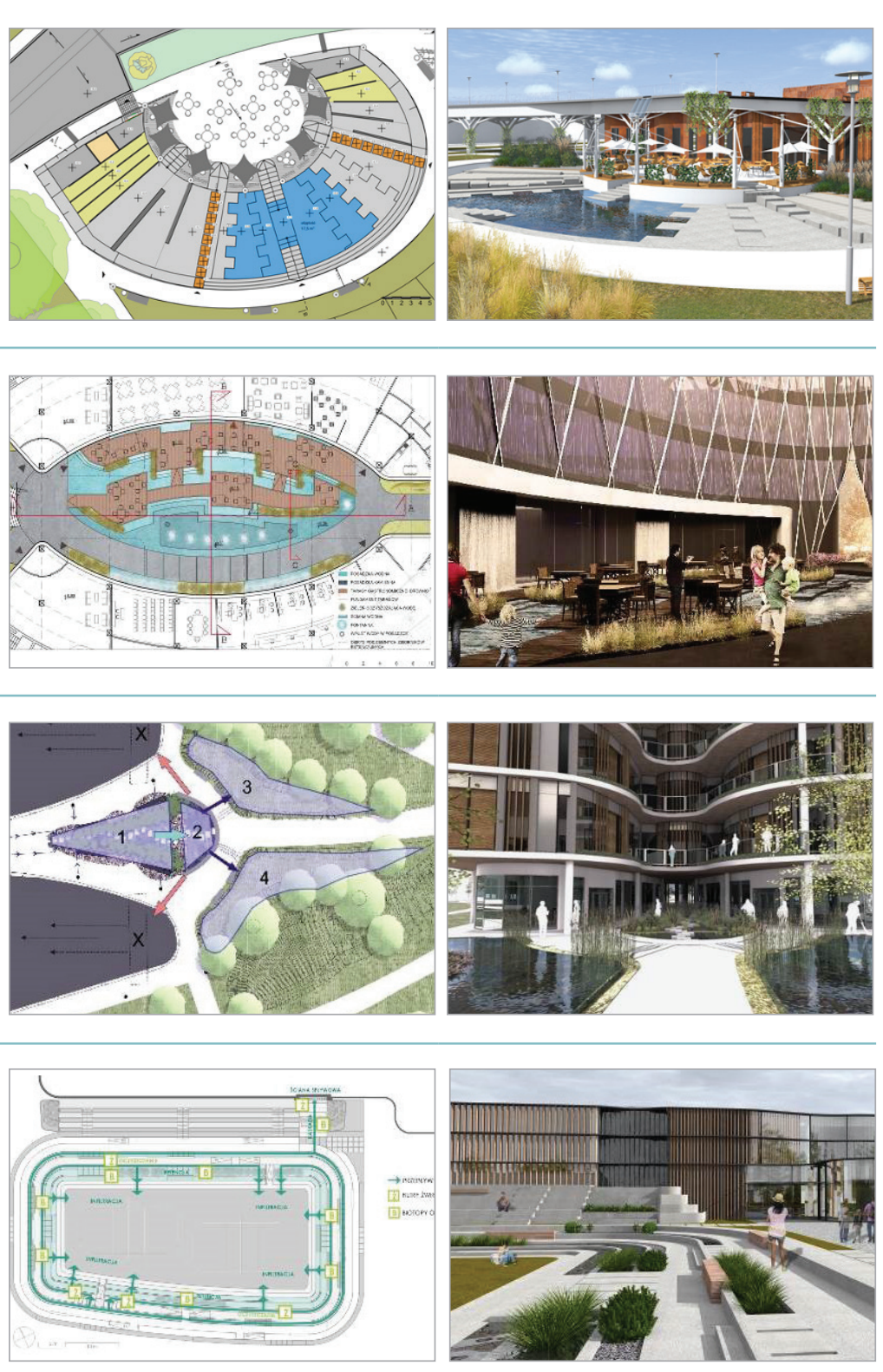

The variant water squares' arrangements underwent the evaluation with the use of IDEKWA method (Table 3) which analyses the key attributes of good public spaces: 1. integration, 2. availability, 3. edutainment, 4. comfort and safe use, 5. the place image, 6. functional attractiveness. Each category was analysed with regard to six specific elements ${ }^{3}$ which were rated on a scale of 0 to 5 , with the use of an expert method. Also, the methods of cleaning, retention, use and draining the excess water were compared along with the maintenance and the running costs.

The highest rate was given to the following projects: 1. Aquadrat, 2. Reed Maze and 8. Water Pitch. However, all the squares were attractive and suitable for individual places. Additional bonus of the projects No 1 and 2 was their module design as well as the possibility of various internal arrangements.

3 The detailed criteria of the assessment are presented in Table 4. 
Table 2

The results of evaluation comparison of good public space attributes (IDEKWA) - the arithmetic mean of rating

\begin{tabular}{|c|c|c|c|c|c|c|c|c|}
\hline $\begin{array}{l}\stackrel{0}{Z} \\
\text { E } \\
\Phi \\
\pm\end{array}$ & $\begin{array}{c}\text { The square } \\
\text { name }\end{array}$ & Integration & Availability & Edutainment & $\begin{array}{l}\text { Comfort and } \\
\text { safe use }\end{array}$ & $\begin{array}{l}\text { The place } \\
\text { image }\end{array}$ & $\begin{array}{c}\text { Functional } \\
\text { attractive- } \\
\text { ness }\end{array}$ & $\begin{array}{l}\text { Mean } \\
\text { rating }\end{array}$ \\
\hline 1 & Aquadrat & 4,5 & 4,286 & 4,333 & 3,833 & 4,333 & 4,333 & 4,270 \\
\hline 2 & Reed Maze & 3,667 & 3,857 & 4 & 4,333 & 4,167 & 4,167 & 4,032 \\
\hline 3 & Hexwater & 4,333 & 4 & 3 & 4 & 3,833 & 2,833 & 3,667 \\
\hline 4 & $\begin{array}{l}\text { Cruciform } \\
\text { Water Square }\end{array}$ & 3,5 & 3,429 & 3,667 & 3,5 & 4,167 & 3 & 3,544 \\
\hline 5 & Croissant & 4,333 & 3,429 & 3,667 & 4 & 4,167 & 3,667 & 3,877 \\
\hline 6 & Rainy Gate & 3,833 & 3,714 & 3 & 3,833 & 4,667 & 2,5 & 3,591 \\
\hline 7 & Rain Garden & 3,5 & 3,571 & 3,167 & 4 & 4,5 & 2,333 & 3,512 \\
\hline 8 & Water Pitch & 4,167 & 4,143 & 3,5 & 4 & 4,5 & 3,833 & 4,024 \\
\hline
\end{tabular}

The aim of the third stage of the research (2015) was to create an idea of Modular Water Squares (MWS), developing a model and experimental examination of visual and functional effects of the flow and retention at different rainfall volumes. The starting point was the assessment of the advantages and flaws of different projects of water squares which was used to determine the key requirements for MWS. They, in return, were employed to develop a basic model as well as variant arrangements of the squares' interiors and small architecture. The consecutive stages of the research are going to include hydraulic simulations making it possible to assess the influence of MWS application on the conditions of water flow in watercourses and rainwater drainage system in Poznan.

\section{Modular Water Squares (MWS)}

The idea of Modular Water Squares is a response to three crucial challenges of Polish cities, namely 1. climate changes and urban floods; 2 . demographic changes including the society ageing process and social exclusion phenomena; 3 . city space degradation and the necessity of urban regeneration of blocks of flats housing estates dating back to the second half of the $20^{\text {th }}$ cent. Within the scope of the adjustment to the climate change ${ }^{4}$ (ad.1), the recommended idea of MWS aims to indicate solutions making it possible to retain rainwater, especially the increased torrential rains, in the place of their occurrence. Taking into account the society ageing processes in the European cities (ad.2), the designed squares should be attractive not only to the children and teenagers but also adjusted to the needs of the elderly and the disabled as well as give opportunities of integrating different generations. The squares must meet the demands of good public space both within the scope of spatial order creation and multifunctional space development so that they could contribute to life quality enhancement in the areas undergoing degradation (ad.3).

The size of a basic researched pattern module of the MWS $(12 \times 12 \mathrm{~m})$ resulted from the size of the space between the blocks of flats (Fig. 4) as well as from the volume of the surface runoff from the neighbouring blocks and pavements. However, the squares' interiors can be arranged in an unlimited and unique way. The square shape of the module and the basic ramp pattern allow to set $12 \times 24 \mathrm{~m}$ or $24 \times 24 \mathrm{~m}$ squares which may be applied in bigger housing estate's interiors as well as the ones in parks, by schools, kindergartens, recreation and service facilities.

The required capacity of the square was determined on the basis of the criterion of the amount and frequency of daily rainfall according to the research conducted by IMGW within the "Climate" project (2012). The square is adjusted to retain the rainfall which can cause minor flooding ( $\geq 30 \mathrm{~mm} /$

4 In October 2013 the Polish government enacted The strategic adaptation plan for sectors and areas susceptible to climate change with an outlook to the year 2030. One of the key objectives of the plan is to adjust the spatial policy as well as the methods of planning the cities to climate changes (the course of action 4.2 - Urban spatial policy including climate change). 


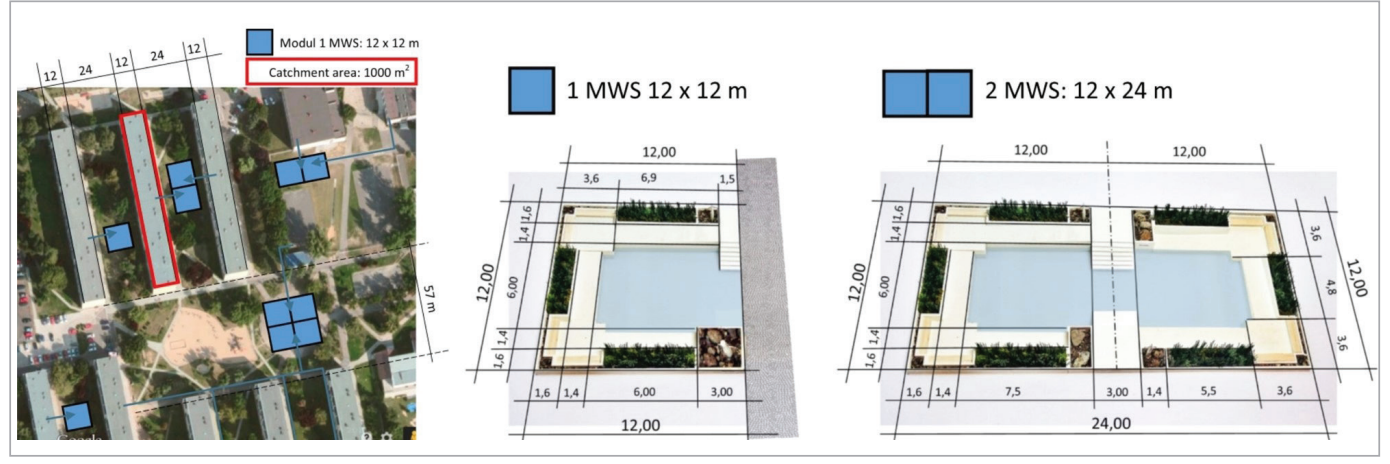

day) and major flooding ( $\geq 50 \mathrm{~mm} /$ day). The project also takes into account the predicted increase in the frequency of extreme phenomena occurrence. In the case of the necessity of extreme rainfall retention of $70 \div 100 \mathrm{~mm} /$ a day or the enlargement of the catchment area's surface, a bigger number of modules must be applied accordingly.

Water square "S" consisting of two modules (total plan surface: $288 \mathrm{~m}^{2}$ and average depth: $0.38 \mathrm{~m}$ ) can receive rainfall of $50 \mathrm{~mm} /$ day from a catchment area of 2,000 $\mathrm{m}^{2}$. In the cases of heavier rainfall or continuing rainfall, exceeding the retention capacity of the square, the emergency flow to infiltration basins and absorbing ditches was designed; or, as a last resort, draining the overflow to rainwater drainage system with considerable delay is also possible. Small rainfall of $5 \div 10 \mathrm{~mm}$ /a day will reinforce reed biotopes $\left(V=21,6 \mathrm{~m}^{3}\right)$, surrounding the square, while the bigger ones of $20 \div 30 \mathrm{~mm} /$ a day will allow to fill up the closed underground retention tanks $\left(2 \times \mathrm{V}=5,8 \mathrm{~m}^{3}\right)$ and the open reservoir in the low level of the square $\left(\mathrm{V}=2,6 \mathrm{~m}^{3}\right)$. The total capacity of the double MWS square can differ from 100 to $110 \mathrm{~m}^{3}$ depending on its internal arrangement.

\section{TRIO system and water circulation}

The TRIO system is a kind of SUDS (Sustainable Urban Drainage Systems) and includes devices and landscape architecture elements which are used to manage rainwater in the place of its occurrence thanks to the natural features of the plants and the soil. The name of the system reflects four main technological processes which are (Januchta-Szostak 2011): (T) transportation, (R) retention, (I) infiltration and $(0)$ purification. The entire process of rainwater management can be divided into three main stages: 1. collecting and transporting, 2. retaining, 3. distributing water through its reuse, sinking and evaporation. The water purification processes can be applied at every of the mentioned stages. The MWS idea takes into account the application of various elements of the TRIO system

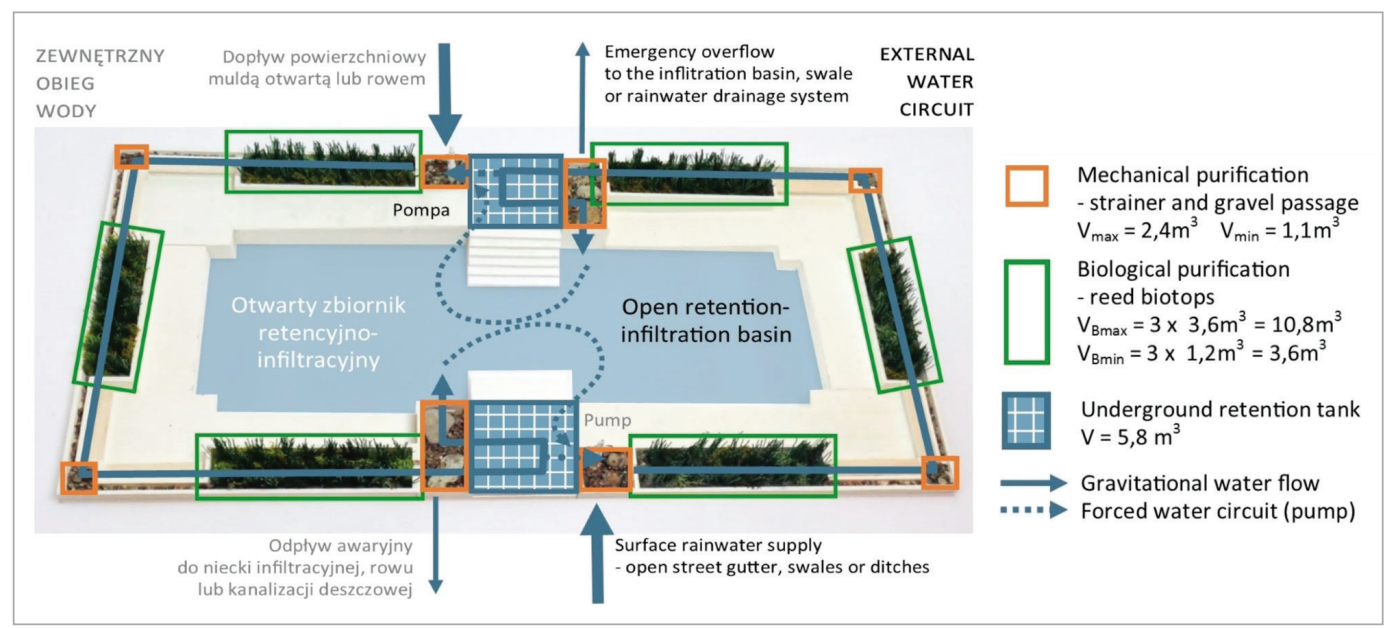

Fig. 4

On the left side: The suggestion of MWS modules' location in a multi-family housing estate (Bohaterów II Wojny Światowej in Rataje district in Poznan). On the right side: Dimensions of the square set from one $(12 \times 12 \mathrm{~m})$ and two modules $(12 \times 24 \mathrm{~m})$ with the ramps pattern without the interior arrangement (developed by A. Januchta-Szostak on the basis of https:// www.google.pl/maps)

\section{Fig. 5}

The TRIO system and the scheme of external water circuit in MWS consisting of two modules (developed by A. Januchta-Szostak) 
(Fig. 5). The circulation system allows to mechanically and biologically purify the water (external water circuit - Fig. 6) as well as to use it for watering plants, playing and decorative purposes. The water from the bottom reservoir can be drawn in by an electric pump and re-transported to the biotopes, passages, cascades or fountains. All the processes of water management are visible to the users of the square which makes it valuable for educational and recreational purposes.

\section{Fig. 6}

Cross sections of the square with two variants of inner arrangement: with a playground on the left side and with a lawn and tree on the right side (developed by A. Januchta-Szostak).

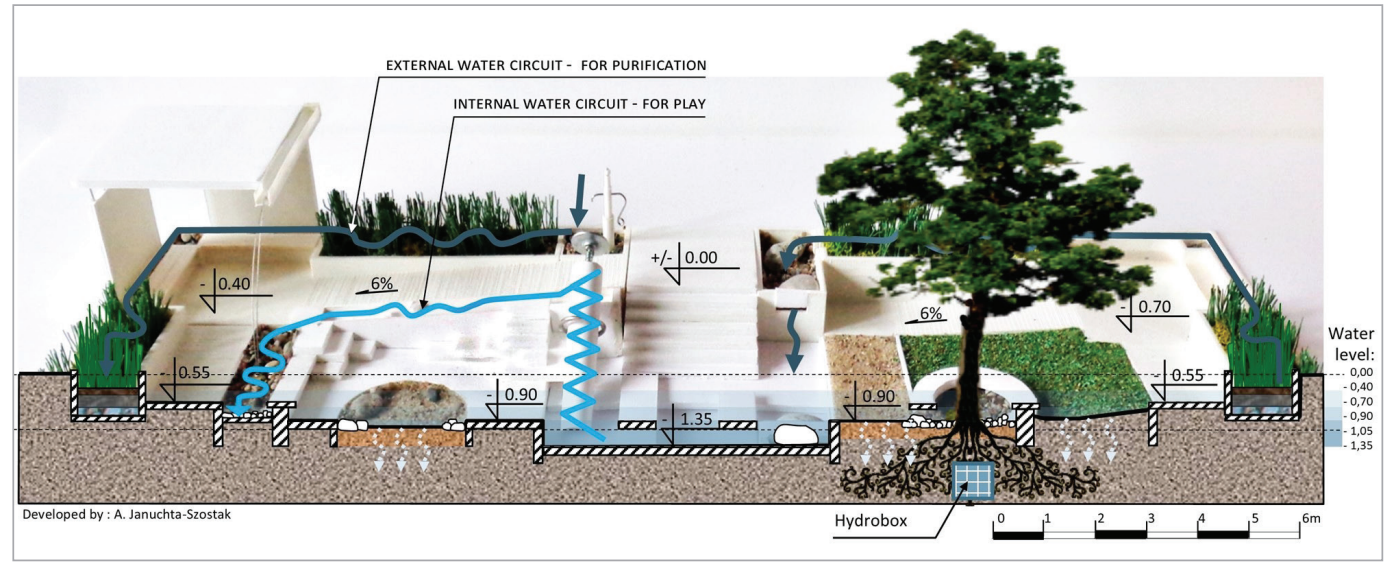

The lowest square level can be reached using stairs or a ramp and can be crossed over on stones or a footbridge (Fig. 6). The square is impervious to the level of $-0.90 \mathrm{~m}$ and contains a shallow, decorative reservoir, which changes depending on the water level. The water is pumped from the lowest reservoir to the retention tank and higher located plant passages. Above the -0.90 $m$ level, the water can infiltrate to the ground through the sandpit or to the circle with a tree. The infiltration abilities depends on the ground structure and the water level. Beside the tree roots, an underground structural chamber can be additionally installed. The chamber (Hydrobox) filled with polymer would absorb the water and gradually return it to the plant.

The development variant with a playground includes creating an internal water circuit, transporting water from the lowest pool upwards with the use of Archimedes' screw (on the left side Fig. 6). Then the water flows in open troughs along the ramps and again reaches the open bottom reservoir. The water course can be enriched by installing valves, water tables and other devices encouraging children to interact with water. The internal water circuit is simultaneously the way of draining runoff from roofs of the rain shelters situated in the corners of the square. During intense rainfall one can safely observe the water cascade falling from gargoyles and flowing in the gravel meanders to the reservoir.

On the area of the square, which can be used for retention functions as a whole, some parts are designed for communication, tranquillity and activity zones as well. Owing to the ramps, different levels of the squares are available to all the users including children, the elderly as well as the disabled in wheelchairs and pedestrians with prams. The ramps between the two water circles constitute also an educational path as they facilitate observation of purification effects, learning about water ecosystems' significance as well as watching the gravitational water runoff on different surfaces and obstructions. The shelters in the corners of the square (Fig. 6) constitute protection from the sun, rain and wind as well as convenient places of rest and observation ${ }^{5}$. Their size and corner location of the benches foster contacts in small six-ten-person groups. The lawn and the retaining walls, integrated with seats, are convenient spots of resting, reading and sunbathing while the sandpit - the favourite place for little children's games. The main attraction, though, is

5 According to Appleton's "prospect-refuge theory" (Appleton 1996), people prefer such places in the landscape where they can observe the space not being seen themselves. 


\begin{tabular}{|c|c|c|}
\hline 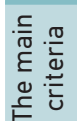 & Elements assessed on a scale from 0 to 5 points & $\begin{array}{l}\text { Mean } \\
\text { rating }\end{array}$ \\
\hline \multirow{7}{*}{ 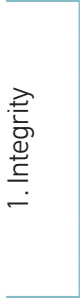 } & the arrangement and facilities of the place fostering interpersonal contacts & 4,875 \\
\hline & opportunities of inter-generational integration in small and bigger groups & 4,375 \\
\hline & providing visual integration (the possibility to see the whole square interior) & 4,5 \\
\hline & integration with the surroundings (arrangement, landscape, functional) & 4,625 \\
\hline & $\begin{array}{l}\text { elements fostering coordination and sharing responsibility for functioning of the small retention } \\
\text { (interactivity) }\end{array}$ & 4,625 \\
\hline & the arrangement flexibility and possibility of changes & 4,75 \\
\hline & I mean rating: & 4,625 \\
\hline \multirow{7}{*}{ 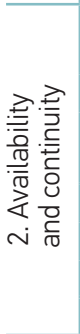 } & $\begin{array}{l}\text { physical availability of different square's levels for all the users including children the elderly and the } \\
\text { disabled (ramps) }\end{array}$ & 4,875 \\
\hline & availability and continuity of the routes on different water levels & 4,75 \\
\hline & $\begin{array}{l}\text { following the water - visibility of the flow, the continuity of water elements' arrangement (following } \\
\text { the flow from the spring to the outlet) }\end{array}$ & 5 \\
\hline & visual and physical contact with water (also for people in the wheelchairs) & 4,875 \\
\hline & using water to manage the access (moats, curtains, partitions etc.) & 4,625 \\
\hline & convenience of availability and easy maintenance & 4,625 \\
\hline & D mean rating: & 4,679 \\
\hline \multirow{7}{*}{ 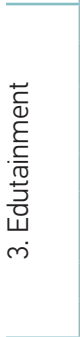 } & using the arrangement and symbolism of water elements to convey a cultural message & 3,5 \\
\hline & enigmatic character - intriguing, fostering the space exploration (adventure with water) & 4,625 \\
\hline & $\begin{array}{l}\text { using water toys (e.g. mini weirs, sluices, valves, drains, pumps, Archimedes' screws, water tables, } \\
\text { sprinkler heads), the possibility of modification by users }\end{array}$ & 4,875 \\
\hline & the opportunity to observe and discover bio-diversity of urban eco-systems (creating habitats) & 4,5 \\
\hline & $\begin{array}{l}\text { visibility of the processes of transportation, retention, infiltration and purification of water (surface } \\
\text { systems of rain water development); showing the stages of hydrological cycle }\end{array}$ & 4,625 \\
\hline & the possibility of using the square to organise educational games or cultural events & 3,875 \\
\hline & E mean rating: & 4,333 \\
\hline \multirow{7}{*}{ 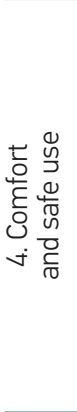 } & $\begin{array}{l}\text { safe use (especially for children) at different water levels, user-friendly form of the rims and the } \\
\text { bottom (steps), the kind of ground surface }\end{array}$ & 4,5 \\
\hline & $\begin{array}{l}\text { arrangement of the place and facilities friendly for different users' groups (children, the elderly and } \\
\text { the disabled), the comfort of use, the seats }\end{array}$ & 4,625 \\
\hline & good visibility and illumination of public places & 3,75 \\
\hline & $\begin{array}{l}\text { using water to enhance microclimate of the place and reduce the negative influence of urban } \\
\text { environment (e.g. vehicle traffic) }\end{array}$ & 4,875 \\
\hline & $\begin{array}{l}\text { the simplicity of water devices' functioning, reliability, easiness of maintenance, damage resilience, } \\
\text { energy saving }\end{array}$ & 4,25 \\
\hline & protection from rain, wind and heat & 4,875 \\
\hline & K mean rating: & 4,479 \\
\hline \multirow{7}{*}{ 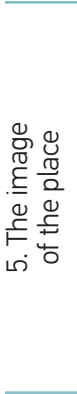 } & water purity - effectiveness of the rain water purification system & 4,75 \\
\hline & $\begin{array}{l}\text { readability and aesthetics of the place (leading, stopping, hierarchical character) coherence of the } \\
\text { architectural arrangement with water and greenery }\end{array}$ & 4,875 \\
\hline & $\begin{array}{l}\text { variability of forms and water arrangements (reflection, movement, changeability, the form of the } \\
\text { edges and the bottom etc.), multi-sensory aesthetic effects: visual, acoustic, aromatic, tactile; using } \\
\text { the changeability of the levels and the dynamics of water arrangement }\end{array}$ & 4,375 \\
\hline & $\begin{array}{l}\text { prestige - raising the rank of the place, representativeness, exposition of architecture and art. with } \\
\text { the water foreground }\end{array}$ & 4,625 \\
\hline & highlighting the identity of the place and its cultural meaning (genius loci) & 4,125 \\
\hline & adequacy of forms and functions in relation to the significance and character of the place & 4,625 \\
\hline & W mean rating: & 4,563 \\
\hline \multirow{8}{*}{ 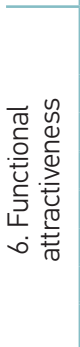 } & $\begin{array}{l}\text { multi-functionality of the square and the water arrangements (functions: bio-climatic, educational, } \\
\text { decorative, recreational isolation-friendly, retention etc.) }\end{array}$ & 4,625 \\
\hline & connecting the blue and green infrastructure with recreation and education (edutainment) & 4,875 \\
\hline & diversification of recreation forms, wide spectrum of activity for different age groups & 4,25 \\
\hline & various possibilities of use in different seasons (the number and kinds of activities) & 3,625 \\
\hline & the attractiveness of use and additional advantages of the square during the rain & 4,375 \\
\hline & zoning of the activity areas (stimulating/calming, integration/isolation) & 4,5 \\
\hline & A mean rating: & 4,375 \\
\hline & Total mean rating: & 4,509 \\
\hline
\end{tabular}

Table 3

The criteria of the assessment of the MWS "S", using the IDEKWA method 
the water as a key decorative, recreational and educational element. The arrangement includes horizontal water planes on different levels, intriguing with reflection effect and varied bottom texture as well as dynamic forms of cascades, fountains and waterfalls which activates movement and changeability along with surprising visual, acoustic and tactile effects. The depth of the pools does not exceed $30 \mathrm{~cm}$ which makes it safe for children. The reservoirs are designed as stair systems so they do not pose any danger at higher water levels.

\section{Public space - evaluation with the use of the IDEKWA method}

The main aim of the project was to correlate the hydro - ecological advantages with high quality of public places. The main criteria of assessment with the use of the IDEKWA method (Januchta-Szostak 2011) include the key features of good public space, namely: (I) integrity, (D) availability, (E) edutainment, (K) usage comfort, (W) image and (A) functional attractiveness. The breakdown (Table 3 ) is a kind of a check list aimed to extensively use water in designing public places. Table 3 also shows the results of an opinion poll conducted within a group of eight experts. The assessment concerned the water square " $\mathrm{S}$ ", consisting of two modules, arranged as a water playground and a lawn.

\section{Conclusions}

Broad application of small retention elements is a crucial component of urban adaptation strategies concerning climate change. MSW-s, designed in accordance with the estimated rainfall volume from the individual catchment areas, can effectively prevent urban flooding simultaneously enhancing the inhabitants' life comfort. Water is the element which intrigues and appeals to people. Therefore, modular water squares can become places of integration, recreation and play while their educational advantages lie in providing knowledge on the significance of the environment and water features. One of the key functions of the squares is edutainment, consisting in learning through entertainment, which facilitates raising the residents' environmental awareness. The arrangement of the squares, which uses the multi-sensory influence of water as well as its changeability and beauty, allows to create places of considerable visual and functional attractiveness. The research proved that well designed squares can be both water-efficient and people-friendly.

Acknow-

The paper was based on two research projects: no 10/01/DSPB/0242 The enhancement of neighbouring and public spaces quality in Poznan with the use of TRIO systems and no 10/01/ DSPB/0252 Ecological design of public spaces and buildings realized by the author at the Faculty of Architecture in Poznan University of Technology, and financed by the Polish Ministry of Science and Higher Education. I am especially grateful to the group of students, who took part in the research studio and participated in the presented projects, namely: J. Grzelak, M. Małecka, K. Niewinowska, J. Nowowieska, S. Sobocińska, J. Stefańska, A. Kubera, A. Skurzynski, M. Kotlarz-Sobańska, J. Smykowska, N. Wiśniewski, J. Zawadzki, A. Florkowska, J. Papierz, M. Karnaś, Z. Mikołajczak, M. Piątkowska, J. Przygórska, K. Budzynowska, M. Rolewska, A. Sazon, D. Gawelski et al.

\section{References}

Appleton J. The Experience of Landscape, New York: John Wiley \& Sons; 1996.

Bergier T, Kronenberg J., Wagner I. (eds.) Water in the city - Sustainable Development Applications Series 5/2014, Kraków: Wyd. Fundacja Sendzimira; 2014, source: http://www.sendzimir.org.pl/images/zrz-5-en/ZRZ5_web.pdf, 18.06.2015.

Boer F., Jorritsma J., van Peijpe D. De urbanisten en het wondere waterplein. Rotterdam: Uitgeverij 010; 2010.
Climate - The research-development project No. POIG 01.03.01-14-011/08-00 „KLIMAT” pt. „Wpływ zmian klimatu na gospodarkę, środowisko i społeczeństwo", task 4: Identyfikacja i ocena ekstremalnych zdarzeń meteorologicznych i hydrologicznych w Polsce w II połowie XX wieku. [The identification and assessment of extreme meteorological and hydrological phenomena in Poland in the second part of $20^{\text {th }}$ cent.]., Warszawa: IMGW; 2012, source: http://klimat.imgw.pl/wp-content/ uploads/2013/01/4_8.pdf, 18.06.2015. 
Echols S., Pennypacker E. Art for Rain's Sake, Landscape Architecture 2006; 97 (9): 24-32.

Januchta-Szostak A. Woda w miejskiej przestrzeni publicznej. Modelowe formy zagospodarowania wód opadowych i powierzchniowych [Water in urban public space. Model forms of rainwater and surface water management]. Poznań: Wyd. Politechniki Poznańskiej; 2011.

Januchta-Szostak A. Poprawa jakości przestrzeni sąsiedzkich i publicznych w Poznaniu z wykorzystaniem systemów zrównoważonego zagospodarowania wód opadowych [The enhancement of neighbouring and public spaces quality in Poznan with the use of TRIO systems], reseach project 10/01/ DSPB/0242 (not published). Poznan: Faculty of Architecture, PUT; 2014.

Rataje - Water Park in Poznan, developed within MA project under the academic supervision of dr hab. inż. arch. A. Januchta-Szostak. Authors: J. Grzelak, M. Małecka, K. Niewinowska, J. Nowowieska, S. Sobocińska, J. Stefańska (not published). Poznan: Faculty of Architecture, PUT; 2014.
Strategiczny Plan Adaptacji dla sektorów i obszarów wrażliwych na zmiany klimatu do 2020 roku z perspektywą do roku 20302030 [The strategic adaptation plan for sectors and areas susceptible to climate change with an outlook to the year 2030], Warszawa: Ministerstwo Ochrony Środowiska; 2013; source: https://klimada.mos.gov.pl/wp-content/uploads/2013/11/SPA-2020.pdf,: 19.06.2015.

Szalińska W., Otop I., Ocena struktury czasowo-przestrzennej opadów z wykorzystaniem wybranych wskaźników do identyfikacji zdarzeń ekstremalnych [The assessment of time-space structure with the use of selected ratings to identify extreme phenomena], Woda-Środowisko-Obszary Wiejskie 2012 (IV-VI): v. 12 z. 2 (38): 269-282.

UNESCO, Water security: responses to local, regional, and global challenges. Strategy plan, Paris: UNESCO IHP; 2012.

WSUD Engineering Procedures: Stormwater, Melbourne Water, Csiro Publishing, Australia; 2005.

\section{ANNA JANUCHTA-SZOSTAK}

Faculty of Architecture, Poznan University of Technology, Poland

\section{Main research area}

water in the townscape, transformation of urban waterfronts, flood protection,

architectural and urban methods of sustainable stormwater management, eco-urbanism

\section{Address}

Nieszawska str. 13C, 61-021 Poznan, Poland

Tel. +48616653280

E-mail: anna.januchta-szostak@put.poznan.pl 